\title{
Limb-girdle muscular dystrophies: Where next after six decades from the first proposal (Review)
}

\author{
OMAR A. MAHMOOD ${ }^{1,2}$ and XIN MEI JIANG ${ }^{1}$ \\ ${ }^{1}$ Department of Neurology, The First Hospital of Jilin University, Changchun, Jilin 130021, P.R. China; \\ ${ }^{2}$ Department of Neuromedicine, Mosul Medical College, Mosul 41002, Iraq
}

Received July 21, 2013; Accepted January 27, 2014

DOI: $10.3892 / \mathrm{mmr} .2014 .2048$

\begin{abstract}
Limb-girdle muscular dystrophies (LGMD) are a heterogeneous group of disorders, which has led to certain investigators disputing its rationality. The mutual feature of LGMD is limb-girdle affection. Magnetic resonance imaging (MRI), perioral skin biopsies, blood-based assays, reverse-protein arrays, proteomic analyses, gene chips and next generation sequencing are the leading diagnostic techniques for LGMD and gene, cell and pharmaceutical treatments are the mainstay therapies for these genetic disorders. Recently, more highlights have been shed on disease biomarkers to follow up disease progression and to monitor therapeutic responsiveness in future trials. In this study, we review LGMD from a variety of aspects, paying specific attention to newly evolving research, with the purpose of bringing this information into the clinical setting to aid the development of novel therapeutic strategies for this hereditary disease. In conclusion, substantial progress in our ability to diagnose and treat LGMD has been made in recent decades, however enhancing our understanding of the detailed pathophysiology of LGMD may enhance our ability to improve disease outcome in subsequent years.
\end{abstract}

\section{Contents}
1. Introduction
2. Historical background
3. Mechanism of action
4. Pathophysiology
5. Disease markers
6. Disease prevalence
7. Genotype-phenotype correlation
8. Diagnostic strategy
9. Prevention and surveillance

Correspondence to: Dr Omar A. Mahmood, Department of Neurology, The First Hospital of Jilin University, 71 Xinmin Street, Changchun, Jilin 130021, P.R. China

E-mail: omarabdulmonem@yahoo.com

Key words: LGMD, MRI, disease biomarkers
10. Management

11. Conclusion

12. Future perspectives

\section{Introduction}

Limb-girdle muscular dystrophies (LGMD) are a group of muscular dystrophies, that until the late 1980s were identified in patients by 'diagnosis by exclusion'. Revolutionary advances in molecular biology in the last several decades have allowed the scientific community to understand and recognize this disease more clearly. Currently, there are >25 LGMD types that have been linked to specific gene loci, and they are now estimated to constitute one third of all Duchenne muscular dystrophy cases (1).

The review is constructed to cover LGMD from a variety of viewpoints and is established on the authors' own experience and investigations, as well as inclusive MEDLINE searches on the topics of 'limb-girdle muscular dystrophies', 'review', 'genotype-phenotype correlations', 'prevention' and 'surveillance'. In this review, we focused on peer-reviewed studies (in English) published in key scientific journals from 1995 to date, combined with several historical articles. All available articles were reviewed in depth. In consideration of the summary and usefulness for clinicians in the field of myology and for future citation, the information and references were summarized into tables.

\section{Historical background}

The term LGMD was, among hereditary muscle disorders, one of the most difficult to establish as a clinical entity. Early definitions were described by Erb where he designated a type of juvenile, scapulohumeral progressive muscular atrophy known as 'a juvenile form of progressive muscular dystrophy'. In 1891, Erb (2) proposed to include with his cases the previous observations of Leyden (3) and Mobius (4). The theory was generally well accepted. Bell (5) was the first to differentiate this type of dystrophy from X-linked Duchenne muscular dystrophy and from autosomal dominant facioscapulohumeral muscular dystrophy. In their archetypal paper, Walton and Nattrass (6) first devised the name 'limbgirdle muscular dystrophies' to comprise cases of both sexes, beginning usually within the first three decades, with major 
Table I. LGMD classification.

\begin{tabular}{|c|c|c|c|c|}
\hline Form & Locus & Gene & Proteinopathies & Key references \\
\hline \multicolumn{5}{|c|}{ Autosomal dominant } \\
\hline LGMD1A & $5 q 31$ & МYOTM & Myotilinopathies & (9) \\
\hline LGMD1B & $1 q 11-q 21$ & $L M N A$ & Lamin $\mathrm{A} / \mathrm{C}$ opathies & $(10)$ \\
\hline LGMD1C & $3 p 25$ & $C A V 3$ & Caveolinopathies & (11) \\
\hline LGMD1D & $2 q 35$ & $D E S$ & Desminopathies & (12) \\
\hline LGMD1E & $7 q 36$ & DNAJBG & HSP40/DNAJ & $(13,14)$ \\
\hline LGMD1F & $7 \mathrm{q} 32.1-\mathrm{q} 32.2$ & - & - & (15) \\
\hline LGMD1G & $4 \mathrm{p} 21$ & - & - & (16) \\
\hline LGMD1H & $3 \mathrm{p} 23-\mathrm{p} 25$ & - & - & (17) \\
\hline \multicolumn{5}{|c|}{ Autosomal recessive } \\
\hline LGMD2A & $15 q 15.1$ & CAPN3 & Calpainopathy & (18) \\
\hline LGMD2B & $2 \mathrm{p} 13$ & $D Y S F$ & Dysferlinopathies & (19) \\
\hline LGMD2C $^{\text {a }}$ & $13 q 12$ & $S G C G$ & $\gamma$-sarcoglycanopathy & $(20)$ \\
\hline LGMD2D $^{\mathrm{a}}$ & $17 q 12-q 21.33$ & $S G C A$ & $\alpha$-sarcoglycanopathy & (21) \\
\hline LGMD2E $^{\mathrm{a}}$ & $4 q 12$ & $S G C B$ & $\beta$-sarcoglycanopathy & (22) \\
\hline LGMD2F $^{a}$ & $5 q 33$ & $S G C D$ & $\delta$-sarcoglycanopathy & (23) \\
\hline LGMD2G & $17 q 12$ & TCAP & Telethoninopathy & (24) \\
\hline LGMD2H & $9 q 31-q 34$ & TRIM32 & E3-ubiquitin ligase & $(25)$ \\
\hline LGMD2I $^{\mathrm{b}}$ & $19 q 13$ & $F K R P$ & Fukutin-related protein & (26) \\
\hline LGMD2J & $2 q 31$ & $T T N$ & Titinopathies & (27) \\
\hline $\mathrm{LGMD} \mathrm{K}^{\mathrm{b}}$ & $9 q 34.1$ & POMTI & POMT1 & $(28)$ \\
\hline LGMD2L & $11 \mathrm{p} 14.3$ & ANO5 & Anoctaminopathies & (29) \\
\hline LGMD2M $^{\mathrm{b}}$ & $9 \mathrm{p} 3$ & $F K T N$ & Fukutinopathies & (30) \\
\hline LGMD2N $\mathrm{N}^{\mathrm{b}}$ & $14 q 10-q 24$ & POMT2 & POMT2 & $(31)$ \\
\hline LGMD2O $^{\mathrm{b}}$ & $1 \mathrm{p} 34-33$ & POMGnT1 & POMGnT1 & (32) \\
\hline LGMD2P $^{b}$ & $3 \mathrm{p} 21$ & $D A G 1$ & Dystroglycan & $(33,34)$ \\
\hline LGMD2Q & $8 \mathrm{q} 24.3$ & PLEC & Plectinopathies & $(35)$ \\
\hline
\end{tabular}

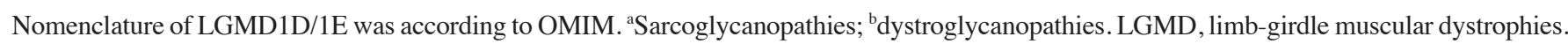

involvement of scapular, pelvic girdle and trunk muscles, with sparing of facial muscles and infrequent pseudo hypertrophy, moderately severe progression and usually an autosomal recessive mode of inheritance.

With the development of physiological and histopathological means to assess muscular disorders, it rapidly seemed that a number of patients considered to be suffering from LGMD were, in fact, affected by other conditions, including spinal muscular atrophies, congenital myopathies or metabolic disorders. Hence, the clinicopathological consistency of this suggested entity was, nevertheless, again promptly disputed.

In the early development of immunostaining methods in the late 1980s, a precise distinction between LGMD and other conditions such as Becker's dystrophy characterized by dystrophin abnormality was established (7).

In 1995, the European Neuromuscular Centre Workshop established more precise criteria for the diagnosis and classification of LGMD. More specifically, different subtypes of LGMD were grouped according to their genetic characteristics (8).
The abbreviation of the autosomal-dominant type is now LGMD1, whereas autosomal-recessive types are LGMD2. Each separate gene locus has a unique classification (Table I) (9-35).

As is evident from its long nosological history, LGMD is not an homogeneous disease. LGMD can be considered an 'umbrella' term under which $>24$ gene defects have been recognized, where single gene defects encode numerous phenotypes and vice versa.

\section{Mechanism of action}

The mechanisms of action of LGMD-involved proteins are diverse. Emphasis is moving away from the identification of structural proteins and their implications in muscular dystrophies towards investigating proteins involved in muscle fiber maintenance in response to repeated injury (dysferlin, caveolin 3 and anoctamin 5), fiber remodeling under stressful conditions (calpain 3), and post-translational modifications of proteins and the enzymes involved in these processes (POMT1, POMT2, POMTGnT1). Despite the advances in modern biochemical techniques, certain proteins still exist without defined functions (Table II) (13,35-51). 


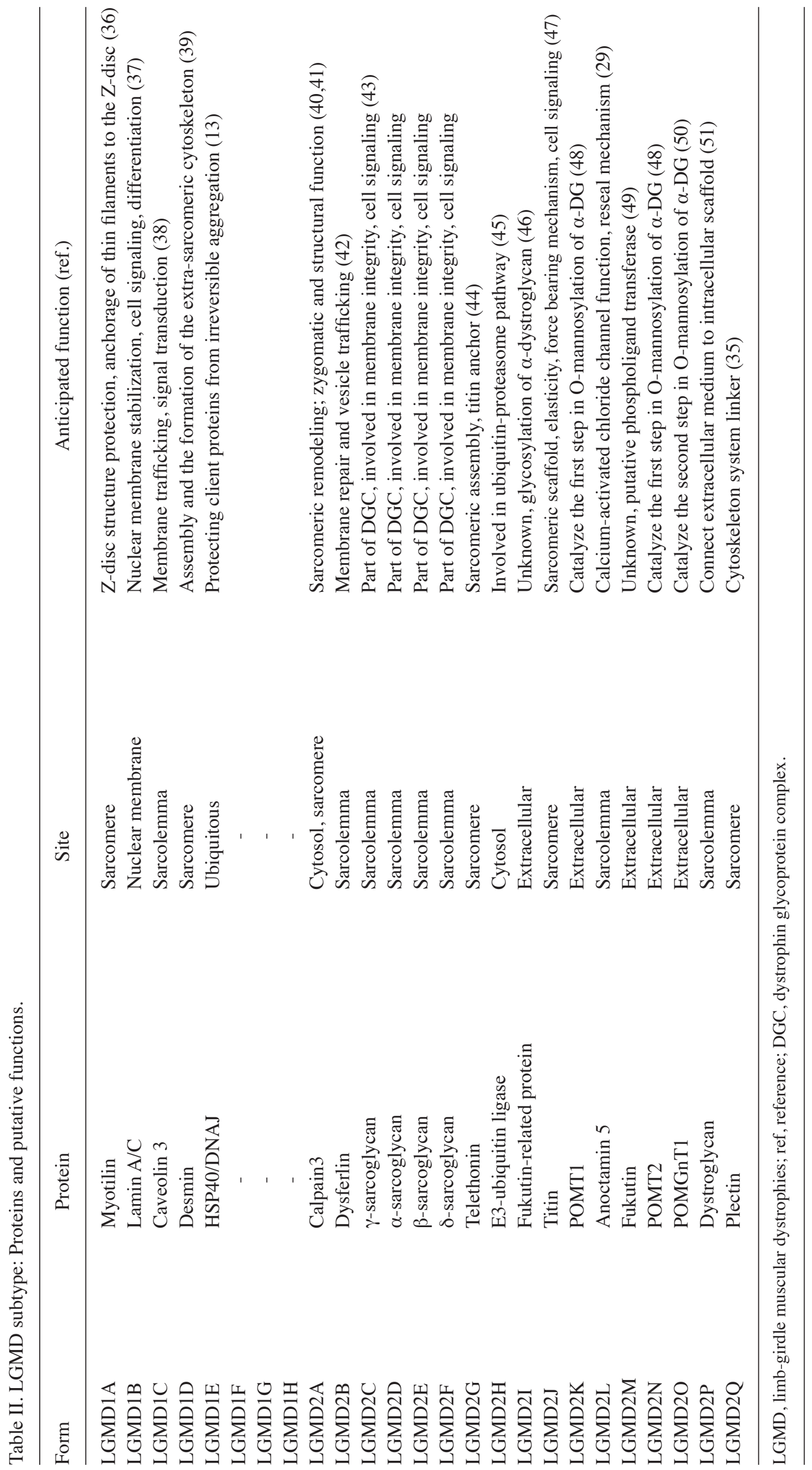




\section{Pathophysiology}

The majority of the developments in LGMD therapeutics have derived from insight gained in animal model investigations, created through the reversal of etiopathogenic agents prompting the disease or by disrupting certain steps believed to be downstream of the defect gene.

When reviewing all mutations in MYOT through the Leiden muscular dystrophy page (http://www.dmd.nl), it was evident that no null mutation has been reported to date in the MYOT gene, hence all mutations are of missense type. This evidence supports the theory that myotilin missense, but not nonsense, mutations are pathogenic in humans and there must be other proteins, such as palladin and myopalladin, which reimburse the structural and functional properties of myotilin (52). This hypothesis is further supported by the fact that the myotilin-null mouse demonstrates normal development, histology and performance, yet myotilin transgenic mice show dystrophic processes and double transgenic mice report a more severe phenotype $(52,53)$. Authors hypothesize that genetic or pharmaceutical interference with mutant myotilin translation, may serve as promising therapeutic approaches in the treatment of LGMD. The LMNA gene encodes the lamin $\mathrm{A} / \mathrm{C}$ protein, which is important in its function as a scaffold for nuclear lamina and as a vital component of cell signaling and differentiation. Currently, three pathways are implicated in the pathophysiology of LMNA-mediated cardiac and musculoskeletal dystrophies; retinoblastoma protein $(\mathrm{pRb})$, mitogen activated protein kinases-extracellular signal-regulated kinases (MAPK-ERK) and transforming growth factor beta ligands (TGF- $\beta$ ). MAPK-ERK and $\mathrm{pRb}$ signaling mediate regulation of the cell cycle, while the TGF- $\beta$ pathway is involved in the transduction of extracellular signals to trigger downstream TGF- $\beta$ gene transcription in the nucleus (37). Several in vivo studies have obtained promising results by targeting these pathways. For example, Muchir et al despite identifying that inhibition of the ERK pathway had a minimal effect on cardiomyopathy, the impact of therapy on cardiac rhythm was not examined; the most common cause of mortality in humans (54). Further studies are essential to elucidate the precise mechanism involved in cardiac arrhythmias and skeletal muscle weakness. Myostatin or TGF- $\beta$ receptor inhibition by various techniques is evolving therapeutic rationales for caveolin 3 mutations. Yet, these treatments were applied to a particular mutation (55). Whether these therapies are effective on other types of mutations or other models remains to be explored.

Accumulating lines of evidence have demonstrated that gene transfer of CAPN3 and mutated myostatin propeptide delivery were efficient therapies in investigations utilizing the calpainopathy murine animal model. However in this study, the duration for gene persistence in muscles was relatively short (9 days), the mode of gene delivery (intramuscular) was not sufficient to improve lifestyle, and the parameters used for assessing improvement were poor, such as the contractile force, which was measured ex vivo (56). Several novel therapeutic strategies have been piloted to treat DYSF gene (DYSF) deficiency. The most well characterized study was that performed by Han et al, who disrupted the complement component $\mathrm{C} 3$ (C3), that is considered to be a crucial mediator of inflammatory cascades in DYSF deficient mice (57). Nonetheless, several queries were raised against the proposed model, including the limitation that the contractile force was not examined. In addition, the authors hypothesized that it is complement activation rather than contraction-induced injuries that is responsible for muscle weakness in the DYSF deficient mouse, however some dysferlinopathic patients have no infiltrates on their biopsies (58). It is unlikely that membrane attack complexes (MAC) underlie muscle weakness, given that the same study identified that $\mathrm{C} 5$ ablation (a terminal component of the MAC pathway) had minimal effects. This issue should be addressed in future trials when utilizing inflammatory and non-inflammatory models. Whether complement C3 inhibitors (easily administered and more convenient for human trials) will have a similar effect as C3 ablation remains to be clarified. In sarcoglycanopthies, various therapeutic stratgies have been investigated in vitro and in vivo, including gene transfer, stem cell grafting, myostatin blockade and calcium channel blockers. Notably, sarcoglycanopathies conveyed more success of gene therapy than other LGMD subtypes due to small size genes. Lastly, calpain 3 inhibition provided a rationale for the treatment of titinopathy.

Though numerous therapies have proved efficacious and safe in several different murine models, caution should be exercised when considering the applicability of these treatments to humans, given the evident differences in size, life span, genetic variants and immunological complexity between the two species. Table III (54-57,59-82) summarizes the majority of murine models constructed and the interventions applied with their results.

\section{Disease markers}

With recent advances in therapeutic trials, more light has been shed on the clinical outcome measures that can be utilized to predict disease activity, regression and treatment efficacy without requiring multiple muscle biopsies.

There are multiple disease markers for LGMD, some of which are well known, and others which have only been identified in recent years. For example, high creatine kinase (CK) levels indicate disease activity; while low levels may indicate fibrosis or therapeutic responsiveness. In cases of local delivery of target therapy, CK level is not helpful. Hand grip strength, Medical Research Council (MRC) scale, Gardner-Medwin and Walton scales or other clinical scales are beneficial for assessing clinical outcome, however inter and intra examiner variability and false-negative results in depressed patients reduces the efficacy and reliability of this method. Another measure utilizes contrast agent-enhanced MRI scanning. Typically, albumin-targeted contrast agent, (MS-325) does not enter into myocytes. In membranopathies, the dye is usually observed in the sarcoplasm. The technique is considered a robust noninvasive disease follow-up tool in the therapeutic trials of the sarcoglycanopathies (83). Measuring the secreted alkaline phosphatase levels (Se AP) in blood (succeeded in murine models), involves insertion of the secreted alkaline phosphatase gene with the gene of interest into a viral vector. Following this, 


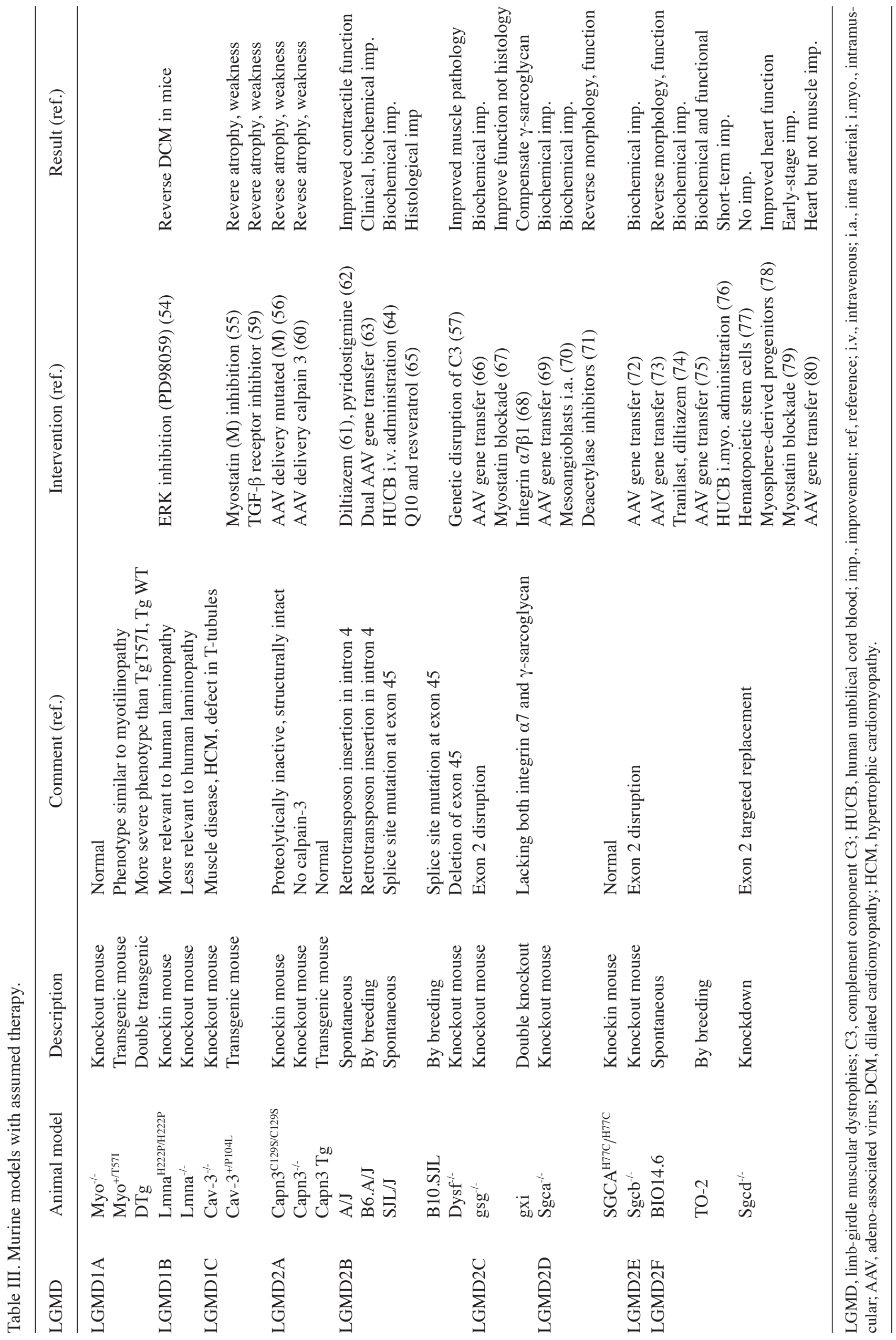




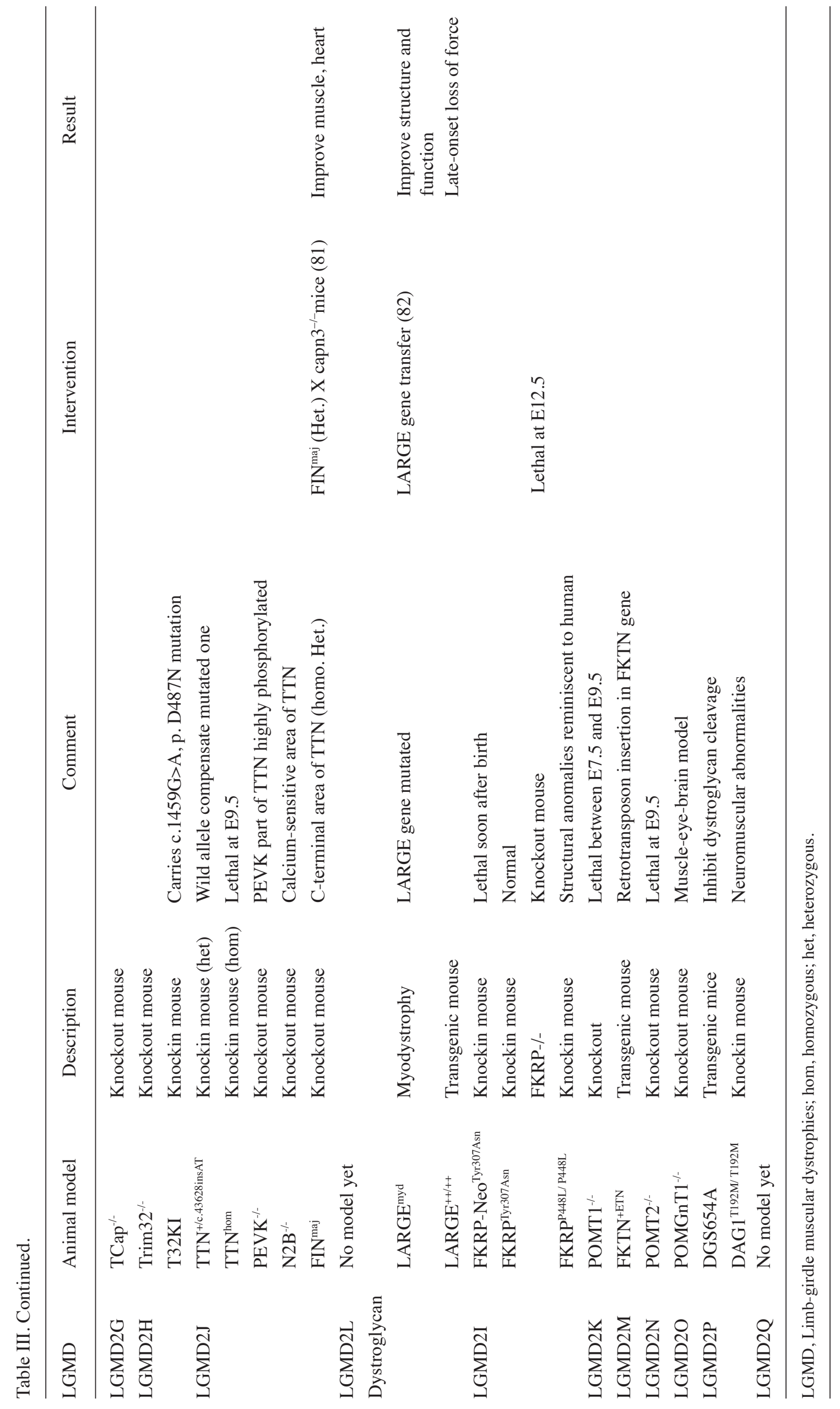




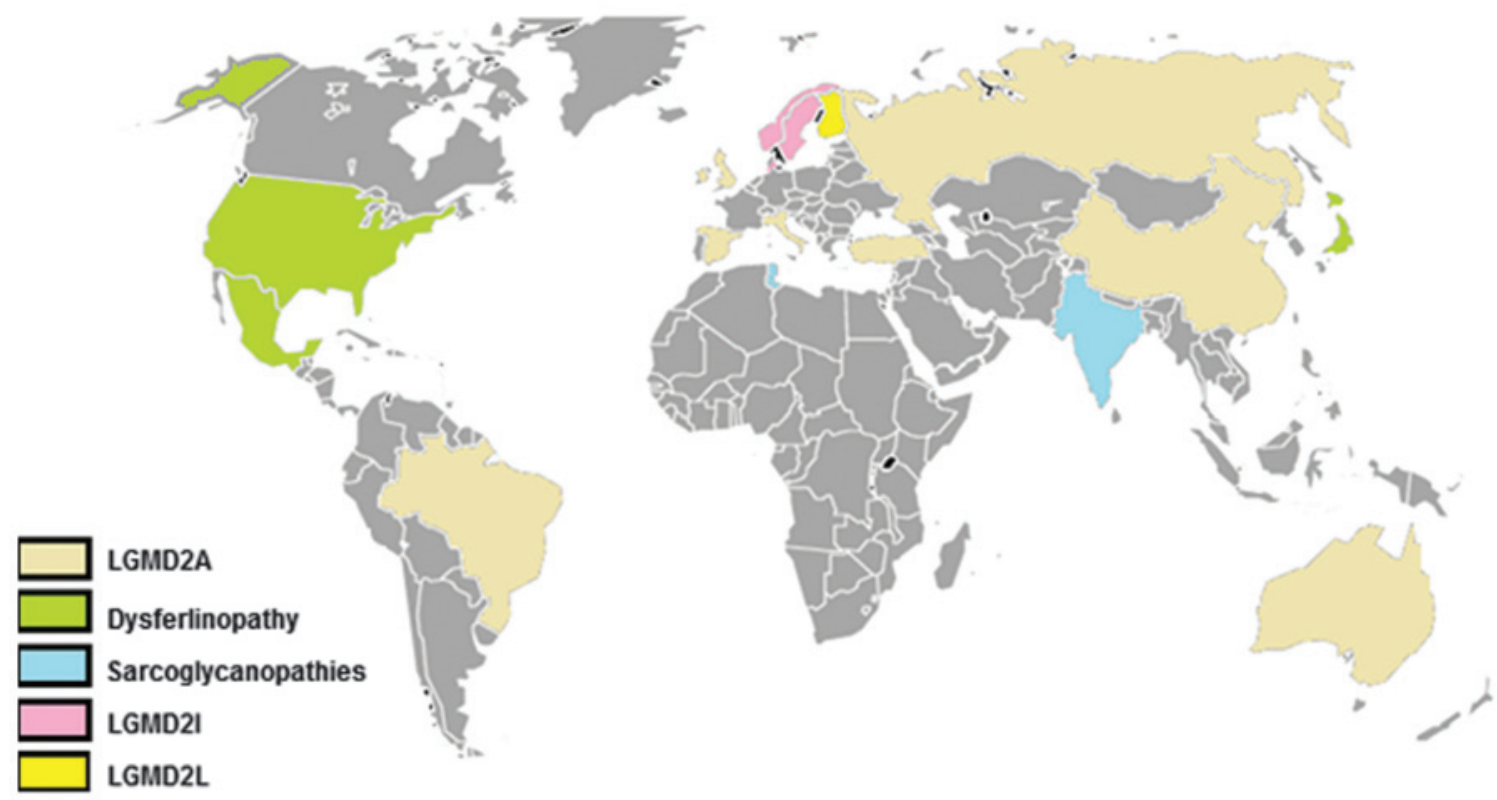

Figure 1. World map with the most common LGMD forms represented in colors. Grey color indicates countries with no known cohort. In Spain, Italy, England, Turkey, Russia, China, Brazil and Australia, the most common type was calpainopathy. LGMD2I was more frequent than other forms in the Scandinavian Peninsula. However, dysferlinopathy was the most frequent in US, Japan and Mexico. In India, sarcoglycanopathies had the highest incidence, whereas in Finland, anoctaminopathy ranked the first (25\%) amongst other forms.

simple blood-based assay of Se AP can predict gene expression in specific muscles. The assay overcomes limitations of CK level identification that is nonspecific and minimally affected in cases of local delivery of the gene (84). Another approach measures dysferlin and calpain 3 expression levels using circulating monocytes that reflect expression level sin muscles given that the target therapy is delivered systemically (61).

Luciferase assay. Luciferase assay is considered as 'regeneration reporter' and its level mirrors the number of centrally nucleated fibers and embryonic heavy chain myosin positive cells (61).

Neutralizing antibodies and interferon (INF)- $\gamma$ to $r A A V$. Measuring antibody titer or mononuclear cell mediated INF- $\gamma$ secretion, by enzyme linked immunosorbent assay (ELISA) and enzyme-linked immunsorboent spot (ELI Spot) assays, respectively, were used to detect degree of immune rejection to inserted vector gene (85).

\section{Disease prevalence}

With the exception of countries such as Norway, Denmark and Finland, where the founder effect was determined, LGMD2A is the most frequent type of LGMD worldwide, followed either by dysferlinopathies in some areas or by sarcoglycanopthies in others (Fig. 1). The relative frequencies of the subtypes that exist among various ethnicities are described in Table IV (86,87,89-92,94-107). LGMD is considered the second most common muscular dystrophy in England, Mexico and Turkey, after dystrophinopathies, with a disease prevalence of up to $1 / 14,500$ and a carrier frequency of up to $1 / 150$ (86-88).

\section{Genotype-phenotype correlation}

Clinical presentations of LGMD disorders vary among patients of the same subtype, or even within the same family (108). Genotype-phenotype correlational analysis is however, difficult to predict and it represents one of the most challenging obstacles in the field of genetic disorders. Trials to elucidate the specific clinical picture for individual genetic subtypes were futile (108).

Currently, two null mutations in the CAPN3 gene have been associated with severe phenotype, early onset and risk of being crippled (90). Natural exon 32 skipping of the DYSF gene notably reduced the severity of symptoms in a mother of two severely affected daughters by homozygous mutation (109). Mild features are most commonly reported in relation to the common Asian mutation c.2997G >T, p.W999C). However, the mutation has also been described in association with a variety of phenotypes (110-112). In cases of LGMD2H, it has been identified that mutations gathered in the NHL (named after the proteins NCL1, HT2A and LIN-41) domain result in LGMD2H/sarcotubular myopathy, whereas in Bardet-Biedl Syndrome, mutations are most commonly located in the B-box region of the gene. This may suggest that mutations in the NHL area render individuals more susceptible to muscular disorders (113). Late disease onset, mild phenotype, less susceptibility to loss of ambulation and more liability to myoglobinuria, are consistent features observed in patients homozygous to c.826C $>$ A (p.L276I) of the FKRP gene compared with patients heterozygous to the same mutation (96). While several LGMD forms are phenotypically heterogeneous, it appears that 'hot spot' c.191dupA mutation in the ANO5 gene is associated with a more homogeneous phenotype (94). Of note, no LGMD2M patients to date have exhibited a $3 \mathrm{~kb}$ retrotransposal insertion in the FKTN gene, a founder mutation accounted for $87 \%$ of Fukuyama type congenital muscular dystrophy (114). Finally, it has been identified that 
Table IV. Relative \% of different LGMD forms in different countries.

\begin{tabular}{|c|c|c|c|c|c|c|c|c|}
\hline \multirow[b]{2}{*}{ Country (ref.) } & \multirow[b]{2}{*}{ No. of patients } & \multicolumn{7}{|c|}{ LGMD } \\
\hline & & $2 \mathrm{~A}$ & $2 \mathrm{~B}$ & $2 \mathrm{C}-\mathrm{F}$ & $2 \mathrm{I}$ & $2 \mathrm{~L}$ & $1 \mathrm{~B}$ & $1 \mathrm{C}$ \\
\hline Italy (89) & 228 & $37 \%$ & $27 \%$ & $23 \%$ & $9 \%$ & $2 \%$ & - & $2 \%$ \\
\hline Italy (90) & 181 & $28.4 \%$ & $18.7 \%$ & $18.1 \%$ & $6.4 \%$ & - & - & $1.3 \%$ \\
\hline Italy (91) & 346 & $25.1 \%$ & $11.2 \%$ & $15 \%$ & $4.3 \%$ & - & $1.4 \%$ & $1.4 \%$ \\
\hline Spain (92) & - & $80 \%$ & - & - & - & - & - & - \\
\hline German (89) & 124 & - & - & - & $16 \%$ & - & - & - \\
\hline UK $(86,94)$ & 68 & $26.5 \%$ & $5.9 \%$ & $11.8 \%$ & $19.1 \%$ & $11.8 \%$ & $8.8 \%$ & - \\
\hline Norway (95) & 326 & - & - & - & $27 \%$ & - & - & - \\
\hline Denmark (96) & 118 & $10.2 \%$ & $1.7 \%$ & $19 \%$ & $32.2 \%$ & - & - & - \\
\hline Finland (97) & 101 & - & - & - & - & $25 \%$ & - & - \\
\hline Australia (98) & 76 & $8 \%$ & $5 \%$ & $2 \%$ & $3 \%$ & - & $1 \%$ & $3 \%$ \\
\hline USA (99) & 226 & $12 \%$ & $18 \%$ & $15 \%$ & $15 \%$ & - & - & $1.5 \%$ \\
\hline Mexico (87) & - & $25 \%$ & $40.6 \%$ & $31.2 \%$ & - & - & - & $3.1 \%$ \\
\hline Turkey (100) & 20 & $50 \%$ & $5 \%$ & $40 \%$ & - & - & - & - \\
\hline Russia (101) & 19 & $75 \%$ & - & - & - & - & - & - \\
\hline Brazil (102) & - & $32 \%$ & $22 \%$ & $32 \%$ & $11 \%$ & - & - & - \\
\hline China (In press) & 68 & $17 \%$ & $15 \%$ & $3 \%$ & - & - & - & $3 \%$ \\
\hline Japan $(103,104)$ & 80 & $26 \%$ & Most & $9 \%$ & - & - & - & - \\
\hline India (105) & 26 & - & - & $53.8 \%$ & - & - & - & - \\
\hline India (106) & 171 & $47 \%$ & - & - & - & - & - & \\
\hline India (107) & 30 & $21 \%$ & - & - & - & - & - & - \\
\hline
\end{tabular}

LGMD, limb-girdle muscular dystrophies; ref, reference.

mutations clustered in immunoglobulin-like fold and coil 2 of the LMNA gene are inconsistently correlated with the autosomal dominant form, LGMD1B (115).

Matching gene expression profiles of normal and affected muscles, identifying the crystalline structure of the protein of interest and recognizing the precise function of each protein domain, are approaches that will improve our understanding of the associations between various pathogenic mutations and disease presentation in LGMD (116).

\section{Diagnostic strategy}

Clinical, electrophysiological, imaging, biochemical and genetic testing techniques collectively should be utilized and tailored according to specific LGMD patient cases. Not only will this facilitate diagnosis and provide individualized genetic counseling to proband and relatives, but will also enhance the understanding of the underlying pathophysiology, to allow delivery of a therapeutic strategy that targets the precise pathways that are specific to that patient.

Clinical. Historical analysis and clinical examination are commonly used approaches to identify specific LGMD subtypes.

Age of onset. The vast majority of autosomal recessive LGMD cases have teenage onset-progressive muscle weakness, however, there are exceptions to this rule. In certain dystroglycanopathies, sporadic dysferlinopathy cases may start exhibiting perinatal 'floppiness' and mild weakness as late as 70 years-old $(117,118)$. While calpainopathy and dysferlinopathies tend to manifest in late childhood to late teens, early childhood onset indicates the diagnosis will be a sarcoglycanopathy or dystroglycanopathy. The majority of, but not all, autosomal dominant LGMD patients begin experiencing symptoms following their twenties.

Pattern of distribution of muscles weakness. LGMD is associated with marked clinical disparity. As the rule of thumb, a defect in membrane scaffolds cause predominant proximal myopathies, whereas sarcomeric protein deficiencies typically result in initial distal myopathies. The exceptions to this include distal Miyoshi myopathies (MMs), which are associated with the membrane patch proteins dysferlinopathy and anoctaminopathy. Scapulohumeral muscle weakness or 'Erb phenotype' is most commonly observed in sarcoglycanopathies, calpainopathies and Duchene's type of LGMD2I, while pelvic muscle weakness or 'Leyden-Mobius phenotype' (LM) is the leading indicator for the majority of LGMD subtypes. While calf, thigh and tongue hypertrophies are mostly encountered in sarcoglycanopthies and dystroglycanopathies, deltoid hypertrophy appears to be restricted to dysferlinopahies $(119,120,121)$.

Skeletal manifestations. Contracture is reported in numerous types of LGMD, however predilection is given to laminopathy, calpainopathy, dystroglycanopathies and anoctminopathy. While kyphoscoliosis and lordosis manifest in calpainopa- 


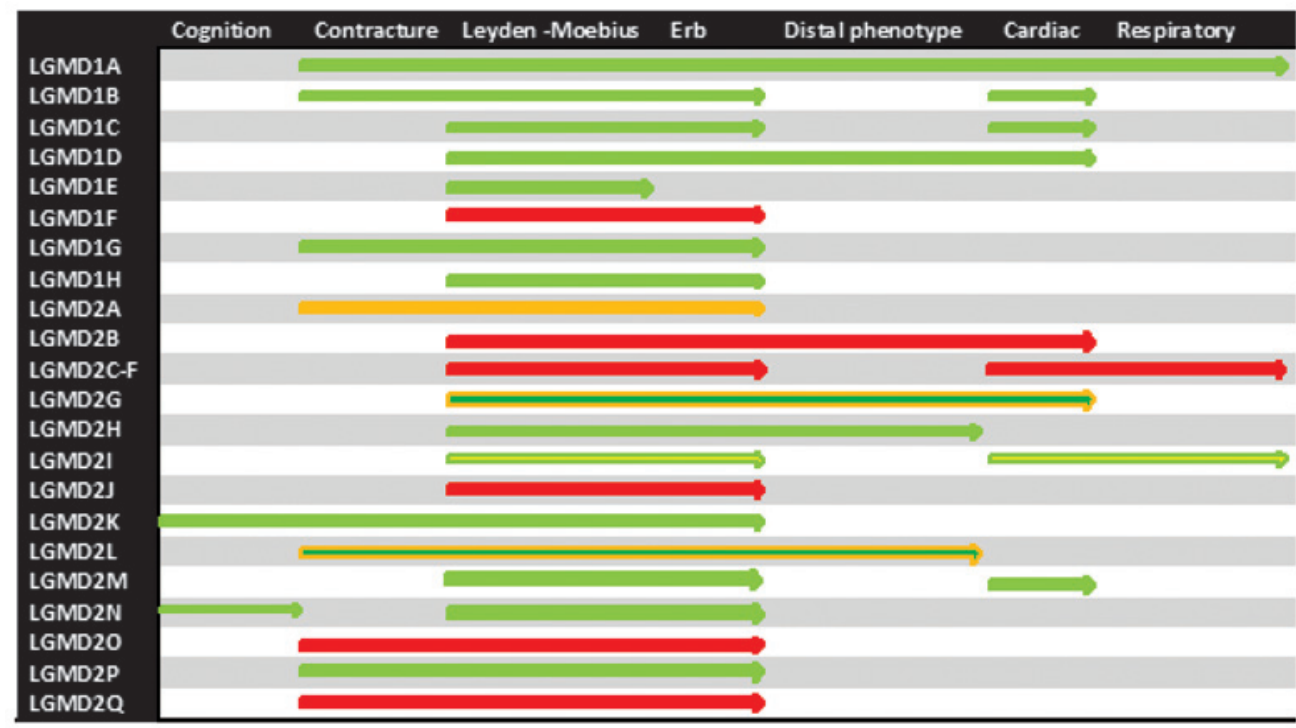

Figure 2. Disease spectrum for rapid recall of LGMD subtypes. Note: green color represents slow progression, yellow color represents moderate progression, red color represents rapid progression and mixed color represents variable progression depending upon either type of the mutation or gender factor (see text).

thies, dystroglycanopathies and plectinopathies, features such as bent and rigid spines, appear to be limited to dysferlinopathies $(112,122)$.

LGMD and heart. With the exception of myotilinopathy, laminopathies, telethoninopathy and LGMD2I, cardiac muscles are spared in the majority of LGMD subtypes or seldom involved in others (LGMD2A, 2B and 2C-2F). Patients with LGMD may present with wide range of cardiac abnormalities e.g., atrial fibrillations, flutters, atrio-ventricular conduction blocks, supraventricular, ventricular ectopic beats, ventricular tachycardia and sudden death commonly seen in the laminopathy patients; on the other side, dilated, hypertrophic and restrictive cardiomyopathy are noticed in some sarcoglycanopathies and a third of LGMD2I cases. Cardiac problems may precede, overlap with or follow skeletal muscle weakness. Periodical cardiac monitoring and pacemaker or defibrillator implantation are warranted in certain cases (123).

LGMD and pulmonary function. Respiratory muscle weakness is a rare manifestation and predominantly indicates diagnosis of LGMD2I, myotilinopathy and occasionally, LGMD2A and LGMD2C-2F. Patients with LGMD2I may also develop respiratory failure while ambulant. Pulmonary function tests should be part of routine examination in suspected LGMD subtypes.

Extra muscular features. Detailed neurological exams often provide an implication of the specific LGMD form. While neuropathy, paresthesia, nasal speech and dysarthria appear to commonly occur in myotilinopathies; opthalmoparesis, foot drop, and paresthesias have been sporadically reported in LGMD1C, $2 \mathrm{G}$ and $2 \mathrm{H}$ respectively $(124,125)$. In dystroglycanopathies, with the exception of LGMD2I, muscle weakness is usually coupled with cognitive impairment, which has serious psychosocial consequences for the patient and their family. Patients with LGMD2I usually have normal intellect, nonetheless there may be some difficulties in visiospatial planning and memory function (126).
Clinical course. LGMD subtypes have a characteristically slow progression, with weakness most commonly beginning in the proximal lower limbs and sometimes the distal limbs. This is followed by weakness in all other limbs and then permanent disability is established two to three decades after disease onset. The subtypes LGMD1D, LGMD2L and LGMD2M represent slowly progressive diseases and patients are mildly affected and remain ambulant (94). Rapid progression is a classical feature of dysferlinopathies, sarcoglycanopathies and plectinopathies. In some LGMD forms there may be inconsistencies in the progression of the disease between male and female-affected patients. In female mild-onset patients, estrogen is considered to impact disease progression. LGMD2G and LGMD2L are examples of LGMD groups with inconsistent disease progression between male and female patients. The study discerned another type of LGMD that is also characterized by a two-peak onset; rapid progressive Duchene like childhood onset and milder Becker-like adolescent to adulthood onset. LGMD2I is representative of this set (96). Fig. 2 denotes disease spectrum for the rapid recall of clinical features of LGMD subtypes.

Clinical constellations. LGMD remains an expanding group of diseases, and approximately one third of cases have not yet been associated with a specific subtype. Certain clinical constellations often favor specific LGMD subtypes, and eliminate a wide array of unnecessary genetic tests. In patients presenting with distal muscular weakness, contractures and cardiac problems in adulthood, myotilinopathy should be considered. Limbgirdle muscle weakness with a family history of sudden death and late onset contractures, most commonly indicate a laminopathy, whereas myalgia, rippling phenomenon, in association with proximal limb muscle weakness in the first four decades of life should raise suspicion of caveolinopathy. Proximal limb muscle weakness with contractures and calf atrophy in teens are features consistently associated with LGMD2A. Early childhood onset muscle weakness with cognitive impairment is a pathognomonic feature of dystroglycanopathies. In 
patients with cardiopulmonary involvement in association with myopathy and myoglobinuria, LGMD2I should be suspected.

\section{Biochemical, imaging and electrophysiological studies.}

Muscle enzymes (CK). CK levels are either normal or mildly elevated in the majority of autosomal dominant LGMDs, whereas in autosomal recessive types, they are highly elevated. While high CK levels in dysferlinopathies, dystroglycanopathies and sarcoglycanopathies are usually correlated with disease activity, calpain 3 deficient patients typically manifest mild to moderate CK level elevation. However, normal and high levels of CK have been sporadically described amongst the disease subtypes. Although CK levels are not specific measurements for the diagnosis of muscular diseases, they often act as a useful tool for guiding physicians to a specific disease process and exclude metabolic or acquired myopathic diseases (127).

Magnetic resonance imaging (MRI). Novel diagnostic tools have been recently introduced to the field of neuromuscular disorders. Studies have utilized modern imaging facilities to facilitate in the diagnosis of highly complicated genetic diseases and to allow physicians to direct patients for further protein and gene testing. The distinction between the most common subtypes (LGMD2A and LGMD2I) that account for up to $80 \%$ of recessive LGMD disorders (in some ethnic groups) is now possible using imaging techniques (128). LGMD2A is characterized by the involvement of gluteus maximus, the posteromedial thigh area and the selective involvement of medial calf muscles. This is in marked contrast to LGMD2I where calf muscles are nonselectively involved. In addition, winging of scapulae and calf atrophy are more evident in calpainopathies than in LGMD2I. The anterior thigh muscles are more affected than the posterior ones in $\alpha$-sarcoglycanopathy, where the calf muscles are relatively spared. This is in contrast to dystrophinopathies, where early and striking changes in the gastrocnemii muscles are prominent $(128,129)$. The specific pattern of affected muscles was eventually delineated in anoctaminopathy, as demonstrated by high signal intensities in posterior thigh muscles, partial atrophy of quadriceps and posteromedial calf affection (89). In myotilinopathy, distal muscle groups represented by the calves are more affected than proximal peroneal muscles and medial pelvic, thigh and lower leg muscles are more involved than lateral sets. The opposite is true for desminopathy (130).

Electrophysiological studies; nerve conduction velocity (NCV) study and electromyography (EMG). Electrophysiological studies are highly important in differentiating myopathic diseases from neurogenic ones, particularly if the patient presents with distal myopathy or contracture deformity where other differential diagnoses, including Charcot-Marie-Tooth syndrome, may be considered. However, neurogenic damages have been sporadically reported in calpainopathy (131) and dysferlinopathy (unpublished observations).

Muscle biopsy: optical and electron microscopy (EM). Muscle biopsy is a transitional step in the diagnostic algorithm of muscle disorders. Several studies are ongoing to simplify the diagnosis of muscular disorders using more superficial tissues like skin (132).

A wide spectrum of optical microscopic alterations, ranging from mild to severe degenerative muscle changes, has been described in LGMD biopsy specimens. Aside from the myopathic features (fiber size variation, internal myonuclei and fiber splitting), inflammatory components appear frequently in biopsy analysis of specific LGMD subtypes like dysferlinopathies (133), anoctaminopathies (94) and dystroglycanopathies and rarely in others, including LGMD2A (134), LGMD2C (135) and LGMD2D (manuscript in press). While rimmed and non-rimmed vacuoles are non-classical features in LGMD disorders (observed mainly in autosomal dominant patients), amyloid deposits are frequently encountered in dysferlinopathies and anoctaminopathies. Features of chronicity, including lobulated fibers, cytochrome $\mathrm{C}$ oxidase (COX) negative fibers and fibers with focal areas of reduced or absent nicotinamide adenine dinucleotide tetrazolium reductase (NADH-TR) are frequently detected in calpainopathy. Desminopathy should be considered in cases with menadionelinked nitro blue tetrazolium (M-NTB) positive cytoplasmic inclusions (12). In cases with only trivial muscle pathology, biopsy analyses are usually non-specific or even normal. However, many genetically confirmed LGMD cases have been mistakably diagnosed as acquired myopathies (136). Hence, EM and immunohistochemistry are essential to establish the diagnosis of LGMD.

EM has a crucial role in diagnostic analyses of certain LGMD subtypes particularly those associataed with myofibrillar proteinopathies. Cytoplasmic filamentous inclusions, spheroid bodies, myofibrillar protein aggregates and Z-disc streaming are features that are commonly diagnosed as myotilinopathies, whereas excess subsarcolemmal granulofilamentous material is in keeping with the characteristics of desminopathy (137). With the exception of laminopathy and myotilinopathies, myonuclei are usually spared in LGMD, which is a feature that facilitates its distinction from sporadic and hereditary inclusion body myopathy. Recently, EMs has been used to explore etiopathogenic mechanism underlying some dystrophic processes. These studies identified plasma membrane defects, basal lamina duplications and submembranous flocculations detected in LGMD2B and LGMD2L as the key indicators of a membrane reseal defect. Of note, some features e.g., vacuolar structures, dilated T tubules and myelin bodies, are non-specific and are shared with a variety of muscular disorders.

Immunohistochemistry (IHC) and western blot (WB) assays. With respect to their diagnostic significance, WB and immunostaining of muscle sections with antibodies against dysferlin (138), sarcoglycans (139), caveolin 3 (140) and telethonin (141) are now the 'gold standards' owing to their high specificities and cost-effectiveness.

In LGMD2A, this approach is often hindered by incomplete sensitivity and specificity. The process of staining muscle sections with available antibodies against calpain 3 is generally disputed as different staining patterns have been detected in abnormal LGMD2A biopsies; however, the specificity of western blotting has been improved by assessing calpain 3 autolytic activity $(142,143)$. In addition, quantitative analyses of calpain 3 bands offer high diagnostic yield ranging from $84 \%$ in certain studies to $100 \%$ in others (144-147).

Other specific antibodies are those raised against the C-terminus of the giant titin proteinandagainst truncated TRIM32 
protein due to compound heterozygous mutations $(148,149)$. A putative broken linkage between the sarcolemma and sarcomere, due to plectin 1f isoform mutation, most commonly results in absent sarcolemma immunostaining that is highly suggestive of plectinopathy. Whereas, reduced expression of dystroglycan- $\alpha$ and laminin- $\alpha 2$ overlay is a sensitive diagnostic indicator for dystroglycanopathies. However, this approach should be interpreted in association with clinical data, to facilitate selecting a specific gene testing method for the patient.

Proper sample handling, freezing and homogenization usually solve the limitation of denatured proteins, when certain antibodies cannot identify and may not be appropriate for biochemical assays. On the other hand, the masking effect of the epitope of an antibody may provide an inaccurate signal and some cases can be easily be overlooked (150).

High expression of calpain 3 and dysferlin in monocytes and the skin has reduced the necessity for muscle biopsies $(132,151)$. Furthermore, multiplex blot analyses technique allows the investigator to envisage protein interaction and secondary reductions more clearly. Also, 'reverse protein array' confers high sensitivity to minimal protein changes that make it suitable to follow-up markers and predict drug responsiveness in upcoming trials (152).

Genetic diagnosis. Careful analysis of clinical and pathological findings and physiological and biochemical data, often provides crucial clues for the diagnosis of a distinct LGMD form. Currently, the documentation of a pathogenic mutation is currently warranted as a tool for identifying the diagnosis of a hereditary muscular disorder.

Genetic analyses are presumed to offer diagnosis for $\sim 99 \%$ of cases with known gene loci. However in some types, such as LGMD 2A, virtually $25 \%$ of cases have no defects in the CAPN3 gene and $22 \%$ have only one affected allele (153). It was estimated $\sim 10-15 \%$ of mutations are either intronic or subtle exonic splice sites. Therefore, muscle flesh, skin or in special cases (LGMD2A, 2B) blood monocytes are necessary to obtain mRNA $(153,154)$. With the exception of selected centers in USA and certain European countries that offer genetic analyses for LGMD patients, genetic diagnosis is only affordable on a research basis. Nonetheless, the common hot spot mutations in certain ethnicities can be targeted prior to running whole gene sequencing (Table V) $(13,14,25,27,35,90,92$, 94,95,96,101,104,141,148,155-162).

As delineated in this review, LGMD is still an underdiagnosed entity and families with no identifiable gene locus may benefit from approaches like linkage analysis (34). Furthermore, gene chips, exome and wide genome sequencing are promising diagnostic tools for the diagnosis of de novo mutations, yet due to the high cost and extensive number of sequence variants, they are limited by challenging monetary and interpretation tasks (163).

\section{Prevention and surveillance}

The optimum time for determination of genetic risk, elucidation of carrier status, and discussion of the availability of prenatal testing, is prior to pregnancy. It is appropriate and necessary to offer genetic counseling to young adults who are affected, are carriers, or are at risk of being carriers. The identification of certain LGMD subtypes has led to changed advice e.g., certain sarcoglycanopathies (autosomal recessive trait) had previously been diagnosed as Becker muscular dystrophy (X-linked recessive trait that mainly transmitted to males) (164).

In certain LGMD disorders, joint contracture, cardiac or respiratory muscle dysfunctions arise earlier and later in the disease course. Regular surveillance with early physiotherapy, orthotics and stretching exercises facilitate joint deformities and delays disabilities for approximately two years (165). Consistent monitoring of cardiac function with early pacemaker or improved implantable cardioverter-defibrillator (ICD) instruments, may rescue the lives of certain laminopathy patients. Consistent monitoring of respiratory function, using of annual influenza vaccines, early physiotherapy, nocturnal ventilation with use of mucolytic and antibiotics if necessary, are all strategies that will reduce the rate of hospitalization and delay the need for tracheostomy and mechanical ventilation for several years. The majority of LGMD patients suffer from depression, social isolation, low self-esteem and culpability (166), so often pyschiatric therapy is of much benefit too.

The patient may be monitored for cardiac and respiratory function in the outpatient neurology clinic, nonetheless, a multi-disciplinary team is recommended to improve outcome and to confirm the optimal timing for intervention. Finally, in cases with unidentified gene defects, should they develop cardiopulmonary or skeletal complications then the above mentioned principles will apply.

\section{Management}

Like other hereditary disorders, despite extensive research, there are currently no therapeutic strategies to treat LGMD. The existing management techniques include emotion and physical support, such as in the use of canes, walkers, splinters, surgical intervention in case of contracture deformities, and support of cardiac and respiratory functions in cases of myotilinopathy, laminopathy and dystroglycanopathy.

Several clinical trials have been completed in humans and others are actively recruiting. These trials in humans have been initiated due to the trials in murine models which successfully demonstrated gene, cell transfer and pharmaceutical therapy in prinicipal (54-82).

While 'replacement therapy' of the defect using gene- or cell-based therapy is the gold standard, pharmaceutical therapy seems to be a more favorable approach, due to the fact the medicine can be evenly distributed to the whole body and is suitable for both modes of inheritance. The proposed pharmaceutical approaches act by targeting specific pathophysiological pathways in the disease. Increasing muscle mass by enhancing positive regulators or by inhibition of negative regulators of muscle growth, such as neutralizing myostatin antibodies, have been utilized in clincal trials, however unfortunately, despite proving safe and tolerable, demonstrated negative results at the endpoints (167). Another therapeutic target is calcium channels, which are more permeable in sarcoglycanopthies, caveolinopathies and other LGMD forms. These observations have been confirmed by reports that anecdotal improvement of CK level was demonstrated in an MM Japanese patient treated with dantrolene to reduce muscle pain, which is a drug that can block calcium channels. Furthermore, a combination of lisinopril (a 


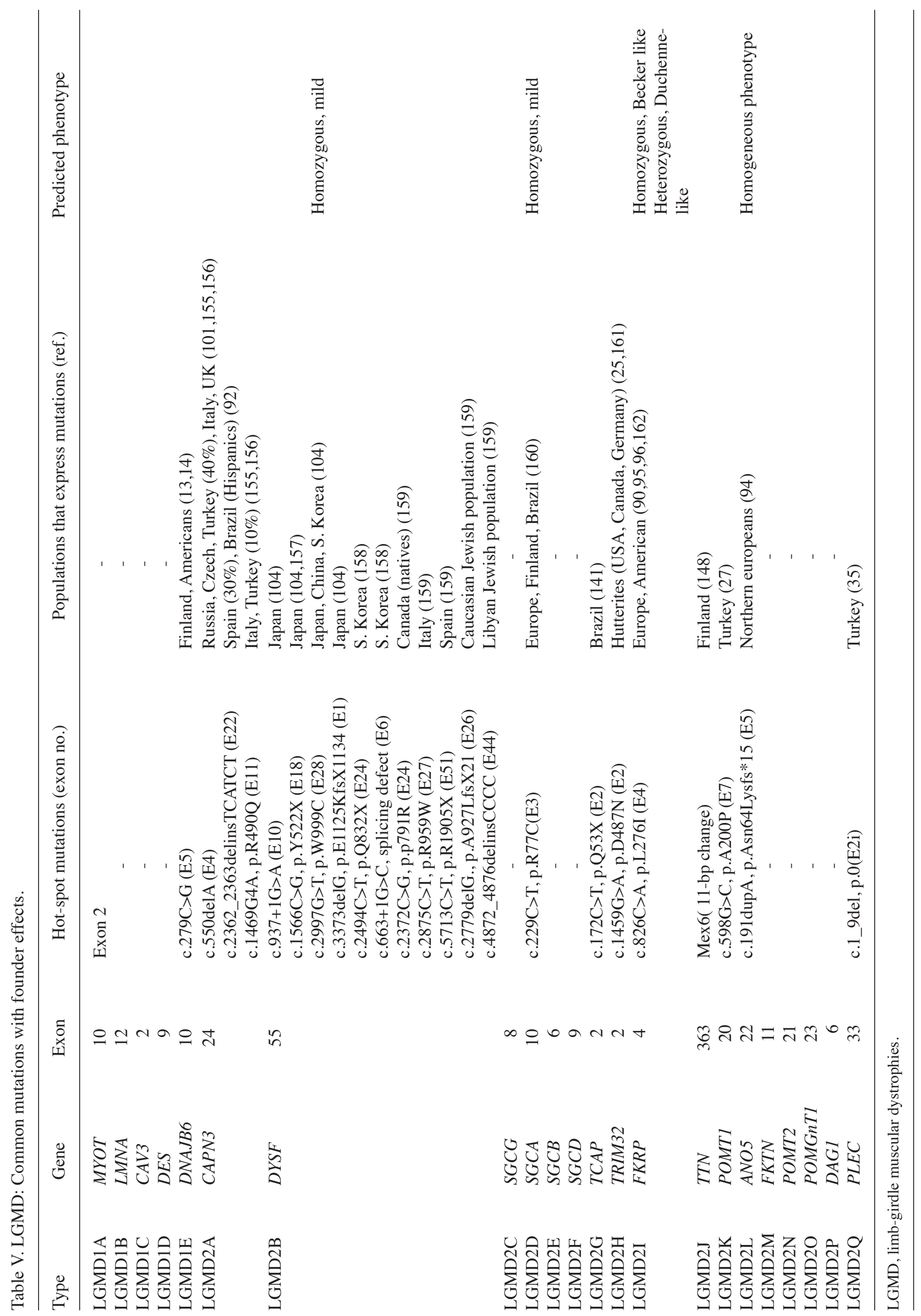




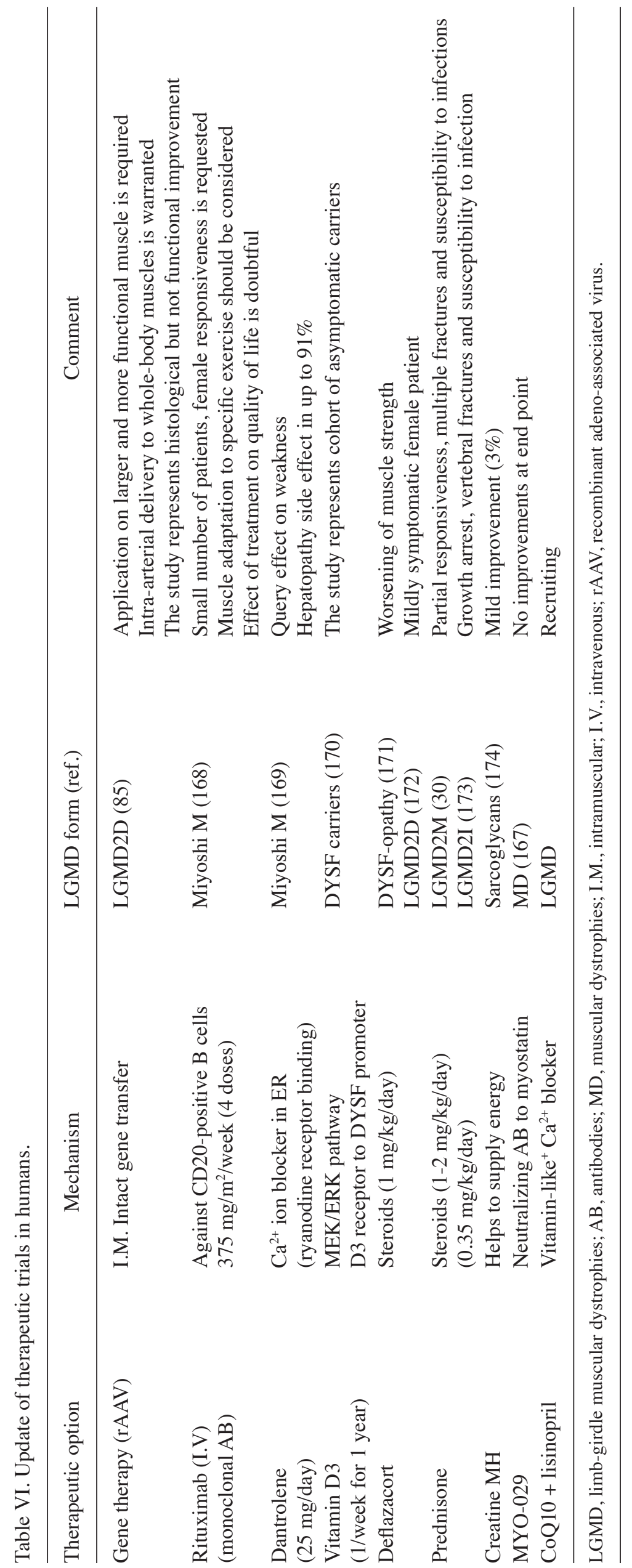


calcium channel blocker agent) and Co Q10 are included in the upcoming trials in the treatment of LGMD. In dysferlinopathies, treatment startegies differ, because inflammatory mechanisms are often active in the DYSF mutant muscles. These approaches include, the use monoclonal antibodies like rituximab to block B cell activation or the use of intravenous immunoglobulin to prevent complement attack complex activations. Recently, vitamin D3 has been shown to possess DYSF promoter properties and has improved dysferlin expression in muscles and monocytes of DYSF mutation carriers (Table VI) (30, 85,167-174). The beneficial effect of steroids in the treatment of sarcoglycanopthies and dystroglycanopathies is a matter of interest, but the mechanism underlying how they improve muscle strength remains elusive. Similarly, this also applies to creatine monohydrate and Co Q10. Another encouraging potential strategy involves the use of calpain inhibitors to stop ubiquitous degradation of misfolded proteins in the Golgi apparatus, however there is no evidence of their effect in humans. Lastly, identifying drugs that upregulate surrogate proteins like $\varepsilon$-sarcoglycan in cases of $\alpha$-sarcoglycanopthies, Integrin $\alpha 7 \beta 1$ in cases of $\gamma$-sarcoglycanopathies, or LARGE in cases of dystroglycanopathies, may also be of potential interest.

\section{Conclusion}

In recent years, our understanding of LGMD has advanced, with regards to disease occurrence, founder effect in some locations, certain aspects of pathophysiology and phenotypegenotype correlations. In addition, elucidation of hot spot mutations, disease biomarkers, general strategies of the diagnosis and treatments would point toward efficient and safe follow up, and intervention. However, more emphasis should be placed on pathogenesis, updating of diagnostic guidelines, with regular assessment and close follow up of disease progression to better elucidate the history of the disease and to enrich translational research. Universal patient registry and collaborated multicenter LGMD disease projects should be encouraged, to provide invaluable insight into its common and unique features and to settle standardized patient care.

\section{Future perspectives}

In the past six decades, advances in the field of molecular biology has opened new avenues to understand the LGMD clinical diagnosis, classification, pathogenesis and treatment possibilities. However, our understanding of the pathophysiology of the majority of LGMD forms is still in its infancy.

The majority of of autosomal dominant disorder mutations behave in a 'dominant negative fashion'. It remains unresolved why single amino acid substitution results in negative adverse function. What is equally intriguing, is whether all mutations act by same mechanism and whether protein interaction with other known and yet undisclosed proteins affect the phenotypes of these diseases. Multiple strategies have been devised to overcome dominant negative cytotoxicity in animal models, including RNA interference, however their safety and efficacy needs to be proved in forthcoming clinical trials.

While the pathogenicity of most autosomal recessive disorders remains to be elucidated, a combination of biochemical tests and the availability of variable animal models have provided invaluable clues for physiological functions of key proteins involved in LGMD. However, it remains unclear how protein deficiencies result in muscle fiber degeneration. A parallel question is why some ubiquitous proteins are involved specifically in muscle diseases. What is equally unclear, is how congenital and adult muscular diseases are produced by the same mutation. The use of a variety of animal models with different types of mutations within the same gene and observing their effects may feasibly solve the 'paradox of single gene and multiple phenotypes'.

\section{Acknowledgements}

This study was supported by the Jilin University Award. The authors would like to thank Mr. Ming Chang and Mr. Yu G. Ma for their technical support.

\section{References}

1. Danièle N, Richard I and Bartoli M: Ins and outs of therapy in limb girdle muscular dystrophies. Int J Biochem Cell Biol 39: 1608-1624, 2007.

2. Erb W: Dystrophia muscularis progressiva. Dtsch Z Nervenheilkd 1: 13-94, 173-261, 1891 (In German).

3. Leyden E: Klinik Der Rückenmarks-Krankheiten. Vol 2. Hirschwald, Berlin, pp531-540, 1875 (In German).

4. Möbius PJ: Ueber die hereditären nervenkrankheiten. Samml Klin Votr 171. Breitkopf und Härtel, Leipzig, pp1505-1531, 1879 (In German).

5. Bell J: On pseudohypertrophic and allied types of progressive Muscular dystrophy. In: The Treasury of Human Inheritance. Fischer RA (ed). Vol 4. Part 4. Cambridge University Press, London, pp283-342, 1943.

6. Walton JN and Nattrass FJ: On the classification, natural history and treatment of the myopathies. Brain 77: 169-231, 1954.

7. Bushby KM and Gardner-Medwin D: The clinical, genetic and dystrophin characteristics of Becker muscular dystrophy. I. Natural history. J Neurol 240: 98-104, 1993.

8. Bushby KM: Diagnostic criteria for the limb-girdle muscular dystrophies: report of the ENMC Consortium on Limb-Girdle Dystrophies. Neuromuscul Disord 5: 71-74, 1995.

9. Hauser MA, Horrigan SK, Salmikangas P, et al: Myotilin is mutated in limb girdle muscular dystrophy $1 \mathrm{~A}$. Hum Mol Genet 9: 2141-2147, 2000.

10. Muchir A, Bonne G, van der Kooi AJ, et al: Identification of mutations in the gene encoding lamins $\mathrm{A} / \mathrm{C}$ in autosomal dominant limb girdle muscular dystrophy with atrioventricular conduction disturbances (LGMD1B). Hum Mol Genet 9: 14531459,2000

11. Minetti C, Sotgia F, Bruno C, et al: Mutations in the caveolin-3 gene cause autosomal dominant limb-girdle muscular dystrophy. Nat Genet 18: 365-368, 1998.

12. Greenberg SA, Salajegheh M, Judge DP, et al: Etiology of limb girdle muscular dystrophy $1 \mathrm{D} / 1 \mathrm{E}$ determined by laser capture microdissection proteomics. Ann Neurol 71: 141-145, 2012.

13. Harms MB, Sommerville RB, Allred P, et al: Exome sequencing reveals DNAJB6 mutations in dominantly-inherited myopathy. Ann Neurol 71: 407-416, 2012.

14. Sarparanta J, Jonson PH, Golzio C, et al: Mutations affecting the cytoplasmic functions of the co-chaperone DNAJB6 cause limbgirdle muscular dystrophy. Nat Genet 44: 450-455, 2012.

15. Palenzuela L, Andreu AL, Gàmez J, et al: A novel autosomal dominant limb-girdle muscular dystrophy (LGMD 1F) maps to 7q32.1-32.2. Neurology 61: 404-406, 2003.

16. Starling A, Kok F, Passos-Bueno MR, Vainzof M and Zatz M: A new form of autosomal dominant limb-girdle muscular dystrophy (LGMD1G) with progressive fingers and toes flexion limitation maps to chromosome 4p21. Eur J Hum Genet 12: 10331040, 2004

17. Bisceglia L, Zoccolella S, Torraco A, et al: A new locus on 3p23-p25 for an autosomal-dominant limb-girdle muscular dystrophy, LGMD1H. Eur J Hum Genet 18: 636-641, 2010.

18. Richard I, Broux O, Allamand V, et al: Mutations in the proteolytic enzyme calpain 3 cause limb-girdle muscular dystrophy type $2 \mathrm{~A}$. Cell 81: 27-40, 1995. 
19. Liu J, Aoki M, Illa I, et al: Dysferlin, a novel skeletal muscle gene, is mutated in Miyoshi myopathy and limb girdle muscular dystrophy. Nat Genet 20: 31-36, 1998.

20. Noguchi S, McNally EM, Ben Othmane K, et al: Mutations in the dystrophin-associated protein gamma-sarcoglycan in chromosome 13 muscular dystrophy. Science 270: 819-822, 1995.

21. Roberds SL, Leturcq F, Allamand V, et al: Missense mutations in the adhalin gene linked to autosomal recessive muscular dystrophy. Cell 78: 625-633, 1994.

22. Lim LE, Duclos F, Broux O, et al: Beta-sarcoglycan: characterization and role in limb-girdle muscular dystrophy linked to 4q12. Nat Genet 1: 257-265, 1995.

23. Nigro V, de Sá Moreira E, Piluso G, et al: Autosomal recessive limb-girdle muscular dystrophy, LGMD2F, is caused by a mutation in the delta-sarcoglycan gene. Nat Genet 14: 195-198, 1996.

24. Moreira ES, Wiltshire TJ, Faulkner G, et al: Limb-girdle muscular dystrophy type $2 \mathrm{G}$ is caused by mutations in the gene encoding the sarcomeric protein telethonin. Nat Genet 24 163-166, 2000

25. Frosk P, Weiler T, Nylen E, et al: Limb-girdle muscular dystrophy type $2 \mathrm{H}$ associated with mutation in TRIM32, a putative E3-ubiquitin-ligase gene. Am J Hum Genet 70: 663-672, 2002

26. Brockington M, Yuva Y, Prandini P, et al: Mutations in the fukutin-related protein gene (FKRP) identify limb girdle muscular dystrophy 2I as a milder allelic variant of congenital muscular dystrophy MDC1C. Hum Mol Genet 10: 2851-2859, 2001.

27. Haravuori H, Vihola A, Straub V, et al: Secondary calpain3 deficiency in 2q-linked muscular dystrophy: titin is the candidate gene. Neurology 56: 869-877, 2001 .

28. Balci B, Uyanik G, Dincer P, et al: An autosomal recessive limb girdle muscular dystrophy (LGMD2) with mild mental retardation is allelic to Walker-Warburg syndrome (WWS) caused by a mutation in the POMT1 gene. Neuromuscul Disord 15 271-275, 2005

29. Bolduc V, Marlow G, Boycott KM, et al: Recessive mutations in the putative calcium-activated chloride channel Anoctamin 5 cause proximal LGMD2L and distal MMD3 muscular dystrophies. Am J Hum Genet 86: 213-221, 2010.

30. Godfrey C, Escolar D, Brockington M, et al: Fukutin gene mutations in steroid-responsive limb girdle muscular dystrophy. Ann Neurol 60: 603-610, 2006.

31. Biancheri R, Falace A, Tessa A, et al: POMT2 gene mutation in limb-girdle muscular dystrophy with inflammatory changes. Biochem Biophys Res Commun 363: 1033-1037, 2007.

32. Clement EM, Godfrey C, Tan J, et al: Mild POMGnT1 mutations underlie a novel limb-girdle muscular dystrophy variant. Arch Neurol 65: 137-141, 2008

33. Hara Y, Balci-Hayta B, Yoshida-Moriguchi T, et al: A dystroglycan mutation associated with limb-girdle muscular dystrophy. N Engl J Med 364: 939-946, 2011.

34. Nigro V, Aurino S and Piluso G: Limb girdle muscular dystrophies: update on genetic diagnosis and therapeutic approaches. Curr Opin Neurol 24: 429-436, 2011.

35. Gundesli H, Talim B, Korkusuz P, et al: Mutation in exon 1f of PLEC, leading to disruption of plectin isoform 1f, causes autosomal-recessive limb-girdle muscular dystrophy. Am J Hum Genet 87: 834-841, 2010.

36. von Nandelstadh P, Grönholm M, Moza M, Lamberg A, Savilahti $\mathrm{H}$, Carpén O: Actin-organising properties of the muscular dystrophy protein myotilin. Exp Cell Res 310: 131-139, 2005.

37. Maraldi NM, Capanni C, Cenni V, Fini M and Lattanzi G: Laminopathies and lamin-associated signaling pathways. J Cell Biochem 112: 979-992, 2011

38. Gazzerro E, Sotgia F, Bruno C, Lisanti MP and Minetti C: Caveolinopathies: from the biology of caveolin-3 to human diseases. Eur J Hum Genet 18: 137-145, 2010.

39. Schröder R and Schoser B: Myofibrillar myopathies: a clinical and myopathological guide. Brain Pathol 19: 483-492, 2009.

40. Ojima K, Ono Y, Ottenheijm C, et al: Non-proteolytic functions of calpain-3 in sarcoplasmic reticulum in skeletal muscles. J Mol Biol 407: 439-449, 2011

41. Ojima K, Kawabata Y, Nakao H, et al: Dynamic distribution of muscle-specific calpain in mice has a key role in physicalstress adaptation and is impaired in muscular dystrophy. J Clin Invest 120: 2672-2683, 2010 .

42. Bansal D, Miyake K, Vogel SS, et al: Defective membrane repair in dysferlin-deficient muscular dystrophy. Nature 423: 168-172, 2003 .
43. Chen YW, Zhao P, Borup R and Hoffman EP: Expression profiling in the muscular dystrophies: identification of novel aspects of molecular pathophysiology. J Cell Biol 151: 1321-1336, 2000.

44. Zou P, Pinotsis N, Lange S, et al: Palindromic assembly of the giant muscle protein titin in the sarcomeric Z-disk. Nature 439: 229-233, 2006.

45. Shieh PB, Kudryashova E and Spencer MJ: Limb-girdle muscular dystrophy $2 \mathrm{H}$ and the role of TRIM32. Handb Clin Neurol 101: 125-133, 2011.

46. Brockington M, Blake DJ, Prandini P, et al: Mutations in the fukutin-related protein gene (FKRP) cause a form of congenital muscular dystrophy with secondary laminin alpha2 deficiency and abnormal glycosylation of alpha-dystroglycan. Am J Hum Genet 69: 1198-1209, 2001

47. Isralewitz B, Gao M and Schulten K: Steered molecular dynamics and mechanical functions of proteins. Curr Opin Struct Biol 11: 224-230, 2001

48. Akasaka-Manya K, Manya H, Nakajima A, Kawakita M and Endo T: Physical and functional association of human protein O-mannosyltransferases 1 and 2. J Biol Chem 281: 19339-19345, 2006.

49. Yamamoto T, Shibata N, Saito Y, Osawa M and Kobayashi M Functions of fukutin, a gene responsible for Fukuyama type congenital muscular dystrophy, in neuromuscular system and other somatic organs. Cent Nerv Syst Agents Med Chem 10: 169-179, 2010.

50. Yoshida A, Kobayashi K, Manya H, et al: Muscular dystrophy and neuronal migration disorder caused by mutations in a glycosyltransferase, POMGnT1. Dev Cell 1: 717-724, 2001.

51. Barresi R and Campbell KP: Dystroglycan: from biosynthesis to pathogenesis of human disease. J Cell Sci 119: 199-207, 2006.

52. Moza M, Mologni L, Trokovic R, Faulkner G, Partanen J and Carpén O: Targeted deletion of the muscular dystrophy gene myotilin does not perturb muscle structure or function in mice. Mol Cell Biol 27: 244-252, 2007.

53. Garvey SM, Liu Y, Miller SE and Hauser MA: Myotilin overexpression enhances myopathology in the LGMD1A mouse model. Muscle Nerve 37: 663-667, 2008

54. Muchir A, Shan J, Bonne G, Lehnart SE and Worman HJ: Inhibition of extracellular signal-regulated kinase signaling to prevent cardiomyopathy caused by mutation in the gene encoding A-type lamins. Hum Mol Genet 18: 241-247, 2009.

55. Kawakami E, Kinouchi N, Adachi T, et al: Atelocollagenmediated systemic administration of myostatin-targeting siRNA improves muscular atrophy in caveolin-3-deficient mice. Dev Growth Differ 53: 48-54, 2011.

56. Bartoli M, Poupiot J, Vulin A, et al: AAV-mediated delivery of a mutated myostatin propeptide ameliorates calpain 3 but not alpha-sarcoglycan deficiency. Gene Ther 14: 733-740, 2007.

57. Han R, Frett EM, Levy JR, et al: Genetic ablation of complement C3 attenuates muscle pathology in dysferlin-deficient mice. J Clin Invest 120: 4366-4374, 2010.

58. Gallardo E, Rojas-García R, de Luna N, Pou A, Brown RH Jr. and Illa I: Inflammation in dysferlin myopathy: immunohistochemical characterization of 13 patients. Neurology 57: 2136-2138, 2001.

59. Ohsawa Y, Okada T, Nishimatsu S, et al: An inhibitor of transforming growth factor beta type I receptor ameliorates muscle atrophy in a mouse model of caveolin 3-deficient muscular dystrophy. Lab Invest 92: 1100-1114, 2012.

60. Bartoli M, Roudaut C, Martin S, et al: Safety and efficacy of AAV-mediated calpain 3 gene transfer in a mouse model of limb-girdle muscular dystrophy type 2A. Mol Ther 13: 250-259, 2006.

61. Albrecht DE, Rufibach LE, Williams BA, Monnier N, Hwang E and Mittal P: 5th Annual Dysferlin Conference 11-14 July 2011, Chicago, Illinois, USA. Neuromuscul Disord 22: 471-477, 2012.

62. Albrecht DE, Garg N, Rufibach LE, et al: 3rd Annual Dysferlin Conference 2-5 June 2009, Boston, Massachusetts, USA Neuromuscul Disord 19: 867-873, 2009.

63. Lostal W, Bartoli M, Bourg N, et al: Efficient recovery of dysferlin deficiency by dual adeno-associated vector-mediated gene transfer. Hum Mol Genet 19: 1897-1907, 2010.

64. Kong KY, Ren J, Kraus M, Finklestein SP and Brown RH Jr.: Human umbilical cord blood cells differentiate into muscle in sjl muscular dystrophy mice. Stem Cells 22: 981-993, 2004.

65. Potgieter M, Pretorius E, Van der Merwe CF, et al: Histological assessment of $\mathrm{SJL} / \mathrm{J}$ mice treated with the antioxidants coenzyme Q10 and resveratrol. Micron 42: 275-282, 2011. 
66. Cordier L, Hack AA, Scott MO, et al: Rescue of skeletal muscles of gamma-sarcoglycan-deficient mice with adeno-associated virus-mediated gene transfer. Mol Ther 1: 119-129, 2000.

67.Bogdanovich S, McNally EM and Khurana TS: Myostatin blockade improves function but not histopathology in a murine model of limb-girdle muscular dystrophy $2 \mathrm{C}$. Muscle Nerve 37: 308-316, 2008.

68. Allikian MJ, Hack AA, Mewborn S, Mayer U and McNally EM: Genetic compensation for sarcoglycan loss by integrin alpha7beta1 in muscle. J Cell Sci 117: 3821-3830, 2004.

69. Allamand V, Donahue KM, Straub V, Davisson RL, Davidson BL and Campbell KP: Early adenovirus-mediated gene transfer effectively prevents muscular dystrophy in alpha-sarcoglycandeficient mice. Gene Ther 7: 1385-1391, 2000.

70. Galvez BG, Sampaolesi M, Brunelli S, et al: Complete repair of dystrophic skeletal muscle by mesoangioblasts with enhanced migration ability. J Cell Biol 174: 231-243, 2006.

71. Minetti GC, Colussi C, Adami R, et al: Functional and morphological recovery of dystrophic muscles in mice treated with deacetylase inhibitors. Nat Med 12: 1147-1150, 2006.

72. Dressman D, Araishi K, Imamura M, et al: Delivery of alphaand beta-sarcoglycan by recombinant adeno-associated virus: efficient rescue of muscle, but differential toxicity. Hum Gene Ther 13: 1631-1646, 2002.

73.Hoshijima M, Hayashi T, Jeon YE, et al: Delta-sarcoglycan gene therapy halts progression of cardiac dysfunction, improves respiratory failure, and prolongs life in myopathic hamsters. Circ Heart Fail 4: 89-97, 2011.

74. Iwata Y, Katanosaka Y, Shijun Z, et al: Protective effects of $\mathrm{Ca} 2+$ handling drugs against abnormal $\mathrm{Ca} 2+$ homeostasis and cell damage in myopathic skeletal muscle cells. Biochem Pharmacol 70: 740-751, 2005.

75.Zhu T, Zhou L, Mori S, et al: Sustained whole-body functional rescue in congestive heart failure and muscular dystrophy hamsters by systemic gene transfer. Circulation 112: 2650-2659, 2005

76. Henning RJ, Aufman J, Shariff M, et al: Human umbilical cord blood mononuclear cells decrease fibrosis and increase cardiac function in cardiomyopathy. Regen Med 5: 45-54, 2010.

77. Lapidos KA, Chen YE, Earley JU, et al: Transplanted hematopoietic stem cells demonstrate impaired sarcoglycan expression after engraftment into cardiac and skeletal muscle. J Clin Invest 114: 1577-1585, 2004

78. Nomura T, Ashihara E, Tateishi K, et al: Skeletal myosphere-derived progenitor cell transplantation promotes neovascularization in delta-sarcoglycan knockdown cardiomyopathy. Biochem Biophys Res Commun 352: 668-674, 2007.

79. Parsons SA, Millay DP, Sargent MA, McNally EM and Molkentin JD: Age-dependent effect of myostatin blockade on disease severity in a murine model of limb-girdle muscular dystrophy. Am J Pathol 168: 1975-1985, 2006.

80. Goehringer C, Rutschow D, Bauer R, et al: Prevention of cardiomyopathy in delta-sarcoglycan knockout mice after systemic transfer of targeted adeno-associated viral vectors. Cardiovasc Res 82: 404-410, 2009.

81. Charton K, Danièle N,, Vihola A, et al: Removal of the calpain 3 protease reverses the myopathology in a mouse model for titinopathies. Hum Mol Genet 19: 4608-4624, 2010.

82. Barresi R, Michele DE, Kanagawa M, et al: LARGE can functionally bypass alpha-dystroglycan glycosylation defects in distinct congenital muscular dystrophies. Nat Med 10: 696-703, 2004.

83. Straub V, Donahue KM, Allamand V, Davisson RL, Kim YR and Campbell KP: Contrast agent-enhanced magnetic resonance imaging of skeletal muscle damage in animal models of muscular dystrophy. Magn Reson Med 44: 655-659, 2000.

84. Bartoli M, Poupiot J, Goyenvalle A, et al: Noninvasive monitoring of therapeutic gene transfer in animal models of muscular dystrophies. Gene Ther 13: 20-28, 2006.

85. Mendell JR, Rodino-Klapac LR, Rosales XQ, et al: Sustained alpha-sarcoglycan gene expression after gene transfer in limbgirdle muscular dystrophy, type 2D. Ann Neurol 68: 629-638, 2010 .

86. Norwood FL, Harling C, Chinnery PF, Eagle M, Bushby K and Straub V: Prevalence of genetic muscle disease in Northern England: in-depth analysis of a muscle clinic population. Brain 132: 3175-3186, 2009

87. Gómez-Díaz B, Rosas-Vargas H, Roque-Ramírez B, et al: Immunodetection analysis of muscular dystrophies in Mexico. Muscle Nerve 45: 338-345, 2012.
88. Diniz G, Eryaşar G, Türe S, et al: A regional panorama of dysferlinopathies. Turk Patoloji Derg 28: 259-265, 2012.

89. Magri F, Bo RD, D'Angelo MG, et al: Frequency and characterisation of anoctamin 5 mutations in a cohort of Italian limb-girdle muscular dystrophy patients. Neuromuscul Disord 22: 934-943, 2012.

90. Guglieri M, Magri F, D'Angelo MG, et al: Clinical, molecular, and protein correlations in a large sample of genetically diagnosed Italian limb girdle muscular dystrophy patients. Hum Mutat 29: 258-266, 2008.

91. Fanin M, Nascimbeni AC, Aurino S, et al: Frequency of LGMD gene mutations in Italian patients with distinct clinical phenotypes. Neurology 72: 1432-1435, 2009.

92. Urtasun M, Sáenz A, Roudaut C, et al: Limb-girdle muscular dystrophy in Guipúzcoa (Basque Country, Spain). Brain 121: 1735-1747, 1998

93. Walter MC, Petersen JA, Stucka R, et al: FKRP (826C>A) frequently causes limb-girdle muscular dystrophy in German patients. J Med Genet 41: e50, 2004.

94. Hicks D, Sarkozy A, Muelas N, et al: A founder mutation in Anoctamin 5 is a major cause of limb-girdle muscular dystrophy. Brain 134: 171-182, 2011

95. Stensland E, Lindal S, Jonsrud C, et al: Prevalence, mutation spectrum and phenotypic variability in Norwegian patients with Limb Girdle Muscular Dystrophy 2I. Neuromuscul Disord 21: 41-46, 2011

96. Sveen ML, Schwartz M and Vissing J: High prevalence and phenotype-genotype correlations of limb girdle muscular dystrophy type 2I in Denmark. Ann Neurol 59: 808-815, 2006.

97. Penttila S, Palmio J, Suominen T, et al: Eight new mutations and the expanding phenotype variability in muscular dystrophy caused by ANO5. Neurology 78: 897-903, 2012.

98. Lo HP, Cooper ST, Evesson FJ, et al: Limb-girdle muscular dystrophy: diagnostic evaluation, frequency and clues to pathogenesis. Neuromuscul Disord 18: 34-44, 2008

99. Moore SA, Shilling CJ, Westra S, et al: Limb-girdle muscular dystrophy in the United States. J Neuropathol Exp Neurol 65: 995-1003, 2006

100. Dinçer P P, Leturcq F, Richard I, et al: A biochemical, genetic, and clinical survey of autosomal recessive limb girdle muscular dystrophies in Turkey. Ann Neurol 42: 222-229, 1997.

101. Pogoda TV, Krakhmaleva IN, Lipatova NA, Shakhovskaya NI, Shishkin SS and Limborska SA: High incidence of 550delA mutation of CAPN3 in LGMD2 patients from Russia. Hum Mutat 15: 295, 2000.

102.Zatz M, de Paula F, Starling A and Vainzof M: The 10 autosomal recessive limb-girdle muscular dystrophies. Neuromuscul Disord 13: 532-544, 2003.

103. Chae J, Minami N, Jin Y, et al: Calpain 3 gene mutations: genetic and clinico-pathologic findings in limb-girdle muscular dystrophy. Neuromuscul Disord 11: 547-555, 2001.

104. Hayashi S, Ohsawa Y, Takahashi T, et al: Rapid screening for Japanese dysferlinopathy by fluorescent primer extension. Intern Med 49: 2693-2696, 2010.

105. Meena AK, Sreenivas D, Sundaram C, et al: Sarcoglycanopathies: a clinico-pathological study. Neurol India 55: 117-121, 2007.

106. Pathak P, Sharma MC, Sarkar C, et al: Limb girdle muscular dystrophy type 2A in India: a study based on semi-quantitative protein analysis, with clinical and histopathological correlation. Neurol India 58: 549-554, 2010.

107. Gayathri N, Alefia R, Nalini A, et al: Dysferlinopathy: spectrum of pathological changes in skeletal muscle tissue. Indian J Pathol Microbiol 54: 350-354, 2011.

108. Hadj Salem I, Kamoun F, Louhichi N, Trigui M, Triki C and Fakhfakh F: Impact of single-nucleotide polymorphisms at the TP53-binding and responsive promoter region of BCL2 gene in modulating the phenotypic variability of LGMD2C patients. Mol Biol Rep 39: 7479-7486, 2012.

109. Sinnreich M, Therrien C and Karpati G: Lariat branch point mutation in the dysferlin gene with mild limb-girdle muscular dystrophy. Neurology 66: 1114-1116, 2006.

110. Tagawa K, Ogawa M, Kawabe K, et al: Protein and gene analyses of dysferlinopathy in a large group of Japanese muscular dystrophy patients. J Neurol Sci 211: 23-28, 2003

111. Takahashi T, Aoki M, Tateyama M, et al: Dysferlin mutations in Japanese Miyoshi myopathy: relationship to phenotype. Neurology 60: 1799-1804, 2003.

112. Nagashima T, Chuma T, Mano Y, et al: Dysferlinopathy associated with rigid spine syndrome. Neuropathology 24: 341-346, 2004. 
113. Saccone V, Palmieri M, Passamano L, et al: Mutations that impair interaction properties of TRIM32 associated with limb-girdle muscular dystrophy 2H. Hum Mutat 29: 240-247, 2008.

114. Kondo-lida E, Kobayashi K, Watanabe M, et al: Novel mutations and genotype-phenotype relationships in 107 families with Fukuyama-type congenital muscular dystrophy (FCMD). Hum Mol Genet 8: 2303-2309, 1999.

115. Scharner J, Gnocchi VF, Ellis JA and Zammit PS: Genotypephenotype correlations in laminopathies: how does fate translate? Biochem Soc Trans 38: 257-262, 2010.

116.Zhang Y, Ye J, Chen D, et al: Differential expression profiling between the relative normal and dystrophic muscle tissues from the same LGMD patient. J Transl Med 4: 53, 2006.

117. Godfrey C, Clement E, Mein R, et al: Refining genotype phenotype correlations in muscular dystrophies with defective glycosylation of dystroglycan. Brain 130: 2725-2735, 2007.

118. Klinge L, Dean AF, Kress W, et al: Late onset in dysferlinopathy widens the clinical spectrum. Neuromuscul Disord 18: 288-290, 2008

119. Rosales XQ, Gastier-Foster JM, Lewis S, et al: Novel diagnostic features of dysferlinopathies. Muscle Nerve 42: 14-21, 2010.

120. Broglio L, Tentorio M, Cotelli MS, et al: Limb-girdle muscular dystrophy-associated protein diseases. Neurologist 16: 340-352, 2010.

121. Mercuri E, Brockington M, Straub V, et al: Phenotypic spectrum associated with mutations in the fukutin-related protein gene. Ann Neurol 53: 537-542, 2003.

122. Gáti I, Danielsson O, Gunnarsson C, et al: Bent spine syndrome: a phenotype of dysferlinopathy or a symptomatic DYSF gene mutation carrier. Eur Neurol 67: 300-302, 2012

123. Hermans MC, Pinto YM, Merkies IS, de Die-Smulders CE, Crijns HJ and Faber CG: Hereditary muscular dystrophies and the heart. Neuromuscul Disord 20: 479-492, 2010.

124. Filosto M, Tonin P, Vattemi G, et al: Chronic ophthalmoparesis in limb girdle muscular dystrophy 1C. J Neurol Neurosurg Psychiatry 80: 448-449, 2009.

125. Selcen D: Myofibrillar myopathies. Neuromuscul Disord 21 161-171, 2011.

126. Palmieri A, Manara R, Bello L, et al: Cognitive profile and MRI findings in limb-girdle muscular dystrophy 2I. J Neurol 258 1312-1320, 2011.

127.Zhang Y, Huang JJ, Wang ZQ, Wang N and Wu ZY: Value of muscle enzyme measurement in evaluating different neuromuscular diseases. Clin Chim Acta 413: 520-524, 2012

128. Wattjes MP, Kley RA and Fischer D: Neuromuscular imaging in inherited muscle diseases. Eur Radiol 20: 2447-2460, 2010.

129. Fischer D, Walter MC, Kesper K, et al: Diagnostic value of muscle MRI in differentiating LGMD2I from other LGMDs. J Neurol 252: 538-547, 2005.

130. Fischer D, Kley RA, Strach K, et al: Distinct muscle imaging patterns in myofibrillar myopathies. Neurology 71: 758-765, 2008.

131. Starling A, de Paula F, Silva H, Vainzof M and Zatz M Calpainopathy: how broad is the spectrum of clinical variability? J Mol Neurosci 21: 233-236, 2003.

132. Santoro L, Nolano M, Faraso S, et al: Perioral skin biopsy to study skeletal muscle protein expression. Muscle Nerve 41: 392-398, 2010

133. Nagaraju K, Rawat R, Veszelovszky E, et al: Dysferlin deficiency enhances monocyte phagocytosis: a model for the inflammatory onset of limb-girdle muscular dystrophy 2B. Am J Pathol 172: 774-785, 2008.

134. Brown RH Jr. and Amato A: Calpainopathy and eosinophilic myositis. Ann Neurol 59: 875-877, 2006.

135. Baumeister SK, Todorovic S, Milić-Rasić V, Dekomien G, Lochmüller H, Walter MC: Eosinophilic myositis as presenting symptom in gamma-sarcoglycanopathy. Neuromuscul Disord 19: 167-171, 2009.

136. Vinit J, Samson M, Jr., Gaultier JB, et al: Dysferlin deficiency treated like refractory polymyositis. Clin Rheumatol 29 103-106, 2010.

137. Claeys KG, Fardeau M, Schröder R, et al: Electron microscopy in myofibrillar myopathies reveals clues to the mutated gene. Neuromuscul Disord 18: 656-666, 2008

138. Cacciottolo M, Numitone G, Aurino S, et al: Muscular dystrophy with marked Dysferlin deficiency is consistently caused by primary dysferlin gene mutations. Eur J Hum Genet 19: 974-980, 2011.

139. Trabelsi M, Kavian N, Daoud F, et al: Revised spectrum of mutations in sarcoglycanopathies. Eur J Hum Genet 16: 793-803, 2008.
140.Herrmann R, Straub V, Blank M, et al: Dissociation of the dystroglycan complex in caveolin-3-deficient limb girdle muscular dystrophy. Hum Mol Genet 9: 2335-2340, 2000.

141. Vainzof M, Moreira ES, Suzuki OT, et al: Telethonin protein expression in neuromuscular disorders. Biochim Biophys Acta 1588: 33-40, 2002.

142. Charlton R, Henderson M, Richards J, et al: Immunohistochemical analysis of calpain 3: advantages and limitations in diagnosing LGMD2A. Neuromuscul Disord 19: 449-457, 2009.

143. Fanin M, Nascimbeni AC, Fulizio L, Trevisan CP, Meznaric-Petrusa $M$ and Angelini C: Loss of calpain-3 autocatalytic activity in LGMD2A patients with normal protein expression. Am J Pathol 163: 1929-1936, 2003.

144. Fanin M, Nascimbeni AC, Tasca E and Angelini C: How to tackle the diagnosis of limb-girdle muscular dystrophy $2 \mathrm{~A}$. Eur J Hum Genet 17: 598-603, 2009.

145. Sáenz A, Leturcq F, Cobo AM, et al: LGMD2A genotype-phenotype correlations based on a large mutational survey on the calpain 3 gene. Brain 128: 732-742, 2005

146. Groen EJ, Charlton R, Barresi R, et al: Analysis of the UK diagnostic strategy for limb girdle muscular dystrophy $2 \mathrm{~A}$. Brain 130: 3237-3249, 2007

147. Fanin M, Fulizio L, Nascimbeni AC, et al: Molecular diagnosis in LGMD2A: mutation analysis or protein testing? Hum Mutat 24: 52-62, 2004

148. Hackman P, Vihola A, Haravuori H, et al: Tibial muscular dystrophy is a titinopathy caused by mutations in TTN, the gene encoding the giant skeletal-muscle protein titin. Am J Hum Genet 71: 492-500, 2002

149. Borg K, Stucka R, Locke M, et al: Intragenic deletion of TRIM32 in compound heterozygotes with sarcotubular myopathy/LGMD2H. Hum Mutat 30: E831-844, 2009.

150. Sewry CA: Muscular dystrophies: an update on pathology and diagnosis. Acta Neuropathol 120: 343-358, 2010.

151. Ho M, Gallardo E, McKenna-Yasek D, De Luna N, Illa I and Brown Jr RH: A novel, blood-based diagnostic assay for limb girdle muscular dystrophy $2 \mathrm{~B}$ and Miyoshi myopathy. Ann Neurol 51: 129-133, 2002.

152. Escher C, Lochmüller H, Fischer D, et al: Reverse protein arrays as novel approach for protein quantification in muscular dystrophies. Neuromuscul Disord 20: 302-309, 2010.

153. Blázquez L, Azpitarte M, Sáenz A, et al: Characterization of novel CAPN3 isoforms in white blood cells: an alternative approach for limb-girdle muscular dystrophy 2A diagnosis. Neurogenetics 9: 173-182, 2008.

154. De Luna N, Freixas A, Gallano P, et al: Dysferlin expression in monocytes: a source of mRNA for mutation analysis. Neuromuscul Disord 17: 69-76, 2007.

155. Teer JK and Mullikin JC: Exome sequencing: the sweet spot before whole genomes. Hum Mol Genet 19: R145-151, 2010.

156. Balci B, Aurino S, Haliloglu G, et al: Calpain-3 mutations in Turkey. Eur J Pediatr 165: 293-298, 2006.

157. Fanin M, Nascimbeni AC, Fulizio L and Angelini C: The frequency of limb girdle muscular dystrophy $2 \mathrm{~A}$ in northeastern Italy. Neuromuscul Disord 15: 218-224, 2005.

158. Takahashi T, Aoki M, Suzuki N, et al: Clinical features and a mutation with late onset of limb girdle muscular dystrophy 2B. J Neurol Neurosurg Psychiatry 84: 433-440, 2012.

159. Park YE, Kim HS, Lee CH, Nam TS, Choi YC and Kim DS: Two common mutations (p.Gln832X and c. $663+1 \mathrm{G}>\mathrm{C}$ ) account for about a third of the DYSF mutations in Korean patients with dysferlinopathy. Neuromuscul Disord 22: 505-510, 2012.

160. Barthélémy F, Wein N, Krahn M, Lévy N, Bartoli M.: Translational research and therapeutic perspectives in dysferlinopathies. Mol Med 17: 875-882, 2011.

161. Hackman P, Juvonen V, Sarparanta J, et al: Enrichment of the R77C alpha-sarcoglycan gene mutation in Finnish LGMD2D patients. Muscle Nerve 31: 199-204, 2005.

162. Schoser BG, Frosk P, Engel AG, Klutzny U, Lochmüller H and Wrogemann K: Commonality of TRIM32 mutation in causing sarcotubular myopathy and LGMD2H. Ann Neurol 57: 591-595, 2005.

163. Kang PB, Feener CA, Estrella E, et al: LGMD2I in a North American population. BMC Musculoskelet Disord 8: 115, 2007.

164. Norwood F, de Visser M, Eymard B, Lochmüller H and Bushby K; EFNS Guideline Task Force: EFNS guideline on diagnosis and management of limb girdle muscular dystrophies. Eur J Neurol 14: 1305-1312, 2007. 
165.Eagle M: Report on the muscular dystrophy campaign workshop: exercise in neuromuscular diseases Newcastle, January 2002. Neuromuscul Disord 12: 975-983, 2002.

166. Miladi N, Bourguignon JP and Hentati F: Cognitive and psychological profile of a Tunisian population of limb girdle muscular dystrophy. Neuromuscul Disord 9: 352-354, 1999.

167. Wagner KR, Fleckenstein JL, Amato AA, et al: A phase I/II trial of MYO-029 in adult subjects with muscular dystrophy. Ann Neurol 63: 561-571, 2008.

168.Lerario A, Cogiamanian F, Marchesi C, et al: Effects of rituximab in two patients with dysferlin-deficient muscular dystrophy. BMC Musculoskelet Disord 11: 157, 2010.

169. Hattori H, Nagata E, Oya Y, et al: A novel compound heterozygous dysferlin mutation in Miyoshi myopathy siblings responding to dantrolene. Eur J Neurol 14: 1288-1291, 2007.

170.Luna ND, Díaz-Manera J, Paradas C, et al: $1 \alpha, 25(\mathrm{OH})$ (2)-Vitamin D3 increases dysferlin expression in vitro and in a human clinical trial. Mol Ther 20: 1988-1997, 2012.
171. Walter MC, Reilich P, Thiele S, et al: Treatment of dysferlinopathy with deflazacort: a double-blind, placebo-controlled clinical trial. Orphanet J Rare Dis 8: 26, 2013.

172. Angelini C, Fanin M, Menegazzo E, Freda MP, Duggan DJ and Hoffman EP: Homozygous alpha-sarcoglycan mutation in two siblings: one asymptomatic and one steroid-responsive mild limb-girdle muscular dystrophy patient. Muscle Nerve 21: 769-775, 1998

173. Darin N, Kroksmark AK, Ahlander AC, Moslemi AR, Oldfors A and Tulinius M: Inflammation and response to steroid treatment in limb-girdle muscular dystrophy 2I. Eur J Paediatr Neurol 11: 353-357, 2007.

174. Walter MC, Lochmüller H, Reilich P, et al: Creatine monohydrate in muscular dystrophies: A double-blind, placebo-controlled clinical study. Neurology 54: 1848-1850, 2000. 